(c) Elsevier Scientific Publishing Company, Amsterdam - Printed in The Netherlands

\title{
ION ADSORPTION MECHANISMS IN OXIDIC SOILS; IMPLICATIONS FOR POINT OF ZERO CHARGE DETERMINATIONS*
}

\author{
W.A. STOOP \\ International Crop Research Institute for Semi-arid Tropics, ICRISAT/UNDP, B.P. 1165, \\ Ouagadougou (Upper Volta)
}

(Received August 4, 1978; accepted after revision October 18, 1979)

\begin{abstract}
Stoop, W.A., 1980. Ion adsorption mechanisms in oxidic soils; implications for point of zero charge determinations. Geoderma, 23: 303-314.

In order to clarify the adsorption mechanisms for various ions (e.g., $\mathrm{P}, \mathrm{K}, \mathrm{Ca}, \mathrm{Mg}$ ), ion adsorption studies were carried out on a range of soils of widely different mineralogical compositions. The soils were classified as: Hydrandept, Gibbsihumox, Eutrustox and Haplustoll and belonged, respectively, to the Honokaa, Halii, Wahiawa and Waialua soil series in Hawaii.

Soils containing mostly hydrous $\mathrm{Fe}$ and $\mathrm{Al}$ oxides, thus colloids of the variable-charge type, retain ions through various types of adsorption mechanisms. As a result, certain interactions between cation adsorption and anion adsorption occur which affect the ion exchange processes and thereby the determination of the point of zero charge (PZC).

In this study adsorbed phosphate increased the adsorption of cations and lowered the PZC and adsorbed Ca interfered with PZC determinations unless these were carried out with $\mathrm{CaCl}_{2}$ as supporting electroly te. It is likely that this latter interference will have influenced the results of many earlier studies because of the very strong adsorption of $\mathbf{C a}$ by oxidic colloids. In this study only part of the adsorbed $\mathrm{Ca}$ could be recovered from the two most highly weathered soils, by repeated extractions with $\mathrm{NH}_{4}$-acetate at $\mathrm{pH} 7$.

The results indicate that many soils of the tropics can be characterized effectively by their PZC's. One should be aware, however, of the effects of strongly adsorbed ions commonly present in these soils and thus use those supporting electrolytes for the PZC determinations which counteract these effects.
\end{abstract}

\section{INTRODUCTION}

Highly weathered soils of the humid tropics, which contain mostly clays of the variable-charge type, possess certain chemical properties which set them apart from less weathered soils in which $2: 1$ layer silicate clays having a permanent charge prevail. These properties include the following.

*The investigations were carried out in the Department of Agronomy and Soils, University of Hawaii, Honolulu, as part of the Ph.D. dissertation of the author. 
(1) A point of zero charge in the soil pH range where plant growth is possible (Van Raij and Peech, 1972; Keng and Uehara, 1973).

(2) A relatively large anion adsorption capacity (Kamprath et al., 1956; Hingston et al., 1968; Kinjo and Pratt, 1971).

(3) High lime requirements to obtain neutral pH (Matsusaka and Sherman, 1964; Rix on, 1966).

(4) Considerable fixation of cations, particularly Ca (Mikami and Kimura, 1964; Rixon, 1966).

Other studies on anion adsorption by oxidic colloids demonstrated that the adsorption increased according to the following series:

$\mathrm{NO}_{3}^{-}<\mathrm{SO}_{4}^{2-}<\mathrm{H}_{2} \mathrm{PO}_{4}^{-}$

(Kinjo and Pratt, 1971). Moreover, Mekaru and Uehara (1972) and Juo and Maduakor (1974) found that strongly adsorbed anions (e.g., phosphates) are associated with increased cation adsorption.

All these phenomena are interrelated. All result from the chemical properties of oxidic colloids. These properties are often difficult to characterize, however, because of their dependence on the $\mathrm{pH}$ and ionic composition of the medium in which measurements are carried out.

In this study, the point of zero charge (PZC) rather than the cation exchange capacity at $\mathrm{pH} 7$ is proposed as a criterion to characterize oxidic soils. Moreover, an easy technique was developed for PZC measurements.

\section{THEORY}

Colloids can be separated into two categories on the basis of the origin of surface charges: those with a permanent charge and those with a variable surface charge.

To the variable-charge colloids belong the oxides and hydrous oxides of $\mathrm{Fe}$ and $\mathrm{Al}$ and the organic colloids. The surface charge on these colloids originates mainly from the association or dissociation of protons with surface hydroxyl groups, as shown for Fe oxides in eq. 1:

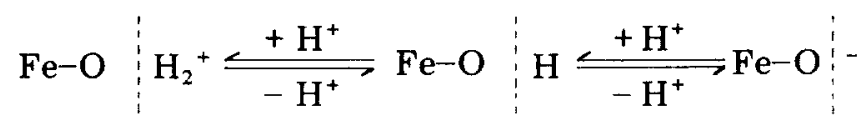

Others prefer to interpret eq. 1 in terms of adsorption of $\mathrm{H}^{+}$or $\mathrm{OH}^{-}$ions, the so-called potential determining ions (Parks and De Bruijn, 1962). Subsequently, the surface charge $\left(\sigma_{0}\right)$ of variable-charge colloids is defined as:

$\sigma_{0}=F\left(\Gamma_{\mathrm{H}^{+}}-\Gamma_{\mathrm{OH}^{+}}\right)$

in which $\Gamma_{\mathrm{H}^{+}}$and $\Gamma_{\mathrm{OH}^{-}}$are, respectively, adsorption of $\mathrm{H}^{+}$and $\mathrm{OH}^{-}$(mequiv./g) and $F$ is the Faraday constant. From $\Gamma_{\mathrm{H}^{+}}=\Gamma \mathrm{OH}^{-}$it follows that the net surface charge $\sigma_{0}=0$, which by definition is the point of zero charge (PZC). Moreover, it appears that near the PZC the oxide surface carries three types of active sites: $-\mathrm{OH}_{2}{ }^{+},-\mathrm{OH}$ and $-\mathrm{O}^{-}$; all of which may contribute to ion adsorption. 
Thus for variable-charge colloids, surface charge and ion adsorption are greatly affected by $\mathrm{pH}$ and also by salt concentration, valency of counterions and specific adsorption of certain ions, e.g., $\mathrm{P}$ adsorption by hydrous $\mathrm{Fe}$ and $\mathrm{Al}$ oxides. Consequently, surface charge or CEC may not be a useful criterion to characterize soils containing mainly colloids of the variable-charge type.

If, however, the procedure outlined by Breeuwsma and Lyklema (1973) for a hematite system is followed, it may be established that non-contaminated surfaces of variable-charge colloids do possess a characteristic point of zero charge. This $\mathrm{PZC}$ is the $\mathrm{pH}$ value at which the surface carries a zero net charge, indicated here as $\mathrm{pH}^{0}$.

The value of $\mathrm{pH}^{0}$ is often determined from the intersection point of titration curves in the presence of different concentrations of an "indifferent" electrolyte (e.g., $\mathrm{NaCl}$ ). Presumably, the increase of the electric capacity of the diffuse double layer upon electrolyte increase, for example, will cause an increase of the surface charge on either side of the $\mathrm{PZC}$. Conversely, $\mathrm{pH}^{0}$ may be found by comparing the change in $\mathrm{pH}$ of suspensions - originally at different $\mathrm{pH}$ value - upon addition of the "indifferent" electrolyte. An increase of the $\mathrm{pH}$ upon addition of salt then indicates an original $\mathrm{pH}$ value below $\mathrm{pH}^{0}$, whereas a decrease occurs for $\mathrm{pH}>\mathrm{pH}^{0}$.

One complication for the above principle is the fact that $\mathrm{pH}^{0}$ may be influenced by certain ions. In the case of sesqui-oxides this is in the first place the chemical adsorption of phosphate ions which will shift the PZC to lower $\mathrm{pH}$ values. Somewhat more complicated is the action of most divalent cations, which also tends to shift the PZC to lower values, presumably because these ions become specifically adsorbed in a Stern-type layer, even at the PZC of the "uncontaminated" surface. This leads to some release of protons, implying that the PZC in the presence of ions such as $\mathrm{Ca}$ will be reached at a lower $\mathrm{pH}$ value. Similar processes may occur in the presence of a divalent anion, e.g., sulfate, in which case, however, protons are adsorbed and the PZC is reached at a higher $\mathrm{pH}$.

Another aspect of oxidic colloids, which may affect their ion adsorption and ion exchange, is the presence of microporosity. Both Breeuwsma (1973), working with hematite, and Tsuji et al. (1975), working with highly weathered soils, concluded that such porosity existed.

In the present study, the value of $\mathrm{pH}^{0}$ was estimated for a number of oxidic soils after various pretreatments by interpolating to a zero value the $\mathrm{pH}$-shift observed when adding certain electrolytes, as discussed later.

\section{MATERIALS AND METHODS}

\section{Soil samples}

The surface soil materials sampled for these studies were developed from different basaltic parent materials under diverse weathering conditions. As a consequence, their mineralogical compositions differ greatly. 


\section{TABLE I}

Classification and some mineralogical and chemical properties of the experimental soils

\begin{tabular}{|c|c|c|c|c|}
\hline Soil series & $\begin{array}{l}\text { Waialua } \\
\text { silty clay }\end{array}$ & $\begin{array}{l}\text { Wahiawa } \\
\text { silty clay }\end{array}$ & $\begin{array}{l}\text { Halii } \\
\text { gravelly } \\
\text { silty clay }\end{array}$ & $\begin{array}{l}\text { Honokaa } \\
\text { silty clay }\end{array}$ \\
\hline Soil classification & $\begin{array}{l}\text { Vertic } \\
\text { Haplustoll }\end{array}$ & $\begin{array}{l}\text { Tropeptic } \\
\text { Eutrustox }\end{array}$ & $\begin{array}{l}\text { Typic } \\
\text { Gibbsihumox }\end{array}$ & $\begin{array}{l}\text { Typic } \\
\text { Hydrandept }\end{array}$ \\
\hline Parent material & $\begin{array}{l}\text { Colluvium } \\
\text { from basaltic } \\
\text { rock }\end{array}$ & Basalt & Basalt & $\begin{array}{l}\text { Basaltic } \\
\text { volcanic ash }\end{array}$ \\
\hline $\begin{array}{l}\text { Mineralogical } \\
\text { composition }\end{array}$ & $\begin{array}{l}\text { Montmoril- } \\
\text { lonite } \\
25-40 \% \\
\text { Kaolinite } \\
1-10 \% \\
\text { Amorphous } \\
10-25 \%\end{array}$ & $\begin{array}{l}\text { Kaolinite } \\
25-40 \% \\
\text { Hematite } \\
10-25 \% \\
\text { Mica } \\
10-25 \%\end{array}$ & $\begin{array}{l}\text { Gibbsite } \\
25-40 \% \\
\text { Goethite } \\
25-40 \% \\
\text { Kaolinite } \\
1-10 \% \\
\text { Amorphous } \\
\text { gels of Fe and } \\
\text { Al oxides } \\
10-25 \%\end{array}$ & $\begin{array}{l}\text { Amorphous } \\
\text { gels of Fe and } \\
\text { Al oxides } \\
>40 \%\end{array}$ \\
\hline Organic matter $(\%)$ & 2 & 3 & 7 & 10 \\
\hline $\begin{array}{l}\text { Si in saturation extract } \\
\quad(\mathrm{ppm})\end{array}$ & 16 & 0.9 & 1.2 & 2.5 \\
\hline $\begin{array}{l}\mathrm{pH}\left(\mathrm{H}_{2} \mathrm{O}\right) \\
\text { Exchangeable cations }\end{array}$ & 6.8 & 5.3 & 5.2 & 4.4 \\
\hline (mequiv./100 g) Ca & 24.8 & 4.0 & 5.0 & 3.3 \\
\hline $\mathbf{M g}$ & 16.6 & 1.2 & 1.7 & 0.5 \\
\hline $\mathrm{K}$ & 1.6 & 0.4 & 0.3 & 0.3 \\
\hline $\mathrm{Na}$ & 1.4 & 0.2 & 0.3 & 0.2 \\
\hline Al & 0 & 0.1 & 0.1 & - \\
\hline $\begin{array}{l}\mathrm{PZC}\left(\mathrm{pH}^{\circ} \text { value) }\right. \\
\quad \text { (in } \mathrm{CaCl}_{2} \text { ) }\end{array}$ & $<3.50$ & 3.75 & 4.00 & 4.25 \\
\hline
\end{tabular}

The samples were secured from unfertilized sites on experimental farms on the islands of Oahu, Hawaii and Kauai. The classification of the soils and a summary of some mineralogical and chemical properties of the samples are given in Table $\mathrm{I}$.

\section{Adsorption studies}

Soil samples ( $3 \mathrm{~g}$ on an oven-dry basis) were equilibrated at various $\mathrm{pH}$ and $\mathrm{P}$ levels for three days (Table II). Subsequently, six different combinations of $\mathrm{K}$ and $\mathrm{Ca}$ were added in the chloride form, maintaining the overall 


\section{TABLE II}

Phosphate and $\mathrm{pH}$ treatments used for the different soil samples

\begin{tabular}{lcccc}
\hline Soil & \multicolumn{2}{l}{$\begin{array}{l}\text { Levels of P added } \\
(\mu \mathrm{gP} / \mathrm{g} \text { soil) }\end{array}$} & $\mathrm{pH}$ treatments \\
\hline Honokaa & 1,500 & 3,000 & 4.8 & 5.8 \\
Halii & 750 & 1,500 & 4.8 & 5.8 \\
Wahiawa & 375 & 750 & 4.8 & 5.8 \\
Waialua & - & 375 & - & 5.8 \\
\hline
\end{tabular}

chloride concentration at $0.01 \mathrm{~N}$. The soil-solution ratio was 1:10. Equilibration with occasional shaking was continued for another $48 \mathrm{~h}$, during which $\mathrm{pH}$ was adjusted to 4.8 or 5.8 by adding $0.2 \mathrm{~N} \mathrm{HCl}$. In a separate study, equilibration periods ranging from $2 \frac{1 / 2}{2}$ to $384 \mathrm{~h}$ were compared.

Next, a sample was centrifuged and the supernatant solution analyzed for $\mathrm{Ca}$ and $\mathrm{K}$. Cations which disappeared from the solution were considered to have been adsorbed.

Cation recovery was estimated from extracts of four $(25 \mathrm{ml})$ washings with $1 \mathrm{~N} \mathrm{NH}_{4}$-acetate at $\mathrm{pH} 7$. The ratio of $\mathrm{Ca}: \mathrm{K}$ on the exchange, complex, as measured in the $\mathrm{NH}_{4}$-acetate extracts, and the corresponding ratio in equilibrium solutions were calculated and plotted to obtain $\mathrm{Ca} / \mathrm{K}$ adsorption preference curves.

\section{Determination of the point of zero charge by the $\mathrm{pH}^{0}$ method}

As explained earlier, the point of zero charge may be determined from the value of $\mathrm{pH}^{0}$. To measure $\mathrm{pH}^{0}$ a serial titration technique was used: $3 \mathrm{~g}$ (oven-dry basis) of sieved, but unwashed, soil samples were equilibrated with $\mathrm{NaOH}$ or $\mathrm{HCl}$ for several days until the $\mathrm{pH}$ remained constant to establish a pH-range of approximately 3.75-7.0. Subsequently, $\mathrm{pH}$ measurements $\left(\mathrm{pH}_{\mathrm{H}_{2} \mathrm{O}}\right)$ were made using a combination electrode.

$\mathrm{Next}, 3 \mathrm{ml}$ of a salt solution were added $\left(\mathrm{NaCl}, \mathrm{Na}_{2} \mathrm{SO}_{4}\right.$ or $\left.\mathrm{CaCl}_{2}\right)$ to bring the salt concentration of the supporting electrolyte to 0.005 or $0.05 \mathrm{~N}$. The resulting change in $\mathrm{pH}\left(\Delta \mathrm{pH}=\mathrm{pH}_{\text {salt }}-\mathrm{pH}_{\mathrm{H}_{2} \mathrm{O}}\right)$ was recorded $3 \mathrm{~h}$ later. The results were plotted against the initial $\mathrm{pH}_{\mathrm{H}_{2} \mathrm{O}}$ value and the $\mathrm{pH}$ value for which $\Delta \mathrm{pH}=0\left(\mathrm{pH}^{0}\right)$ was determined by interpolation. The reproducibility of the method was within $5 \%$.

The $\mathrm{pH}^{0}$ values were determined for all original soil samples at two concentrations of each of $\mathrm{NaCl}, \mathrm{Na}_{2} \mathrm{SO}_{4}$ and $\mathrm{CaCl}_{2}$. Only for the Waialua sample, which contains mainly constant-charge colloids and has a high base status, was it impossible to obtain a $\mathrm{pH}^{0}$ value.

The effects of liming, exchangeable Ca and adsorbed phosphate on $\mathrm{pH}^{\mathbf{0}}$ values, determined in $\mathrm{NaCl}$ and $\mathrm{CaCl}_{2}$, were studied on samples of the Halii and Wahiawa soils. All studies were done with rates of liming and phosphate 
application that were within or near the fertilizer range commonly recommended for these soils in Hawailan agriculture.

Low salt concentrations were employed to prevent unnaturally high competition with adsorbed Al. As reported by Keng and Uehara (1973) desorption of $\mathrm{Al}$ occurred at $1 \mathrm{~N}$ salt concentrations and caused a drop in PZC.

\section{RESULTS AND DISCUSSION}

Cation adsorption processes; interactions with adsorbed phosphate and $p H$

The cation adsorption properties of the four different soil samples and the role of the variable-charge colloids in highly weathered soils were investigated using the following experiments: (a) cation adsorption as a function of time; (b) reversibility of cation adsorption by reextraction of adsorbed cations with $\mathrm{NH}_{4}$-acetate at $\mathrm{pH} 7$; and (c) determination of $\mathrm{Ca} / \mathrm{K}$ adsorption preference curves measured in the presence of $0.01 \mathrm{~N}$ chloride.

With respect to the first two experiments listed above, it was found that $\mathrm{Ca}$ and $\mathrm{K}$ adsorptions in the Waialua and Wahiawa soil samples, both containing $1: 1$ and $2: 1$ layer silicate clays, were completely reversible processes, equilibrium being reached in less than $2 \frac{1}{2} \mathrm{~h}$. For the Honokaa and Halii samples, however, which are both rich in hydrous oxides of $\mathrm{Fe}$ and $\mathrm{Al}$, equilibration took as long as $48 \mathrm{~h}$, and the subsequent recovery of cations was incomplete. This was most pronounced for the Honokaa sample from which $30 \%$ of the adsorbed Ca could not be recovered. For $\mathrm{K}$ and $\mathrm{Mg}$ these values were in the order of $15-20 \%$.

Both the time-dependent adsorption and the incomplete recovery of

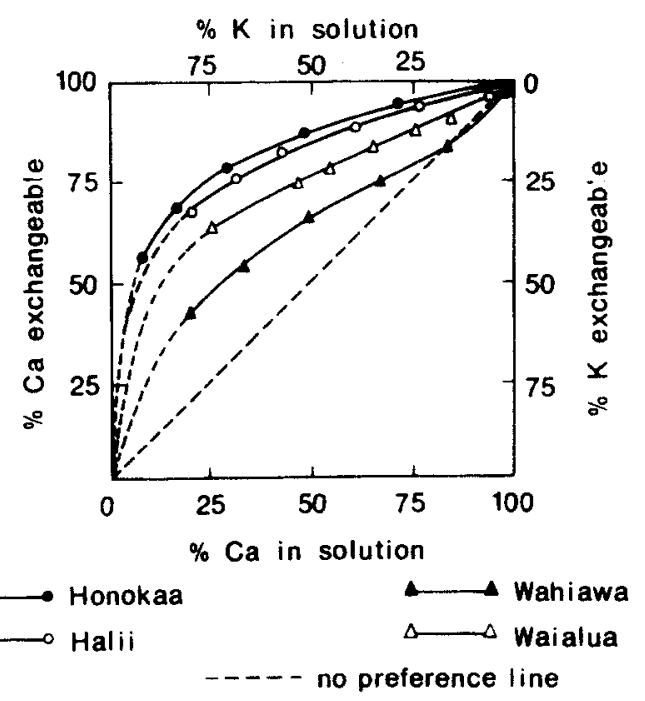

Fig. 1. Cation adsorption preference curves for $\mathrm{Ca} / \mathrm{K}$ ion pairs as influenced by soil type, when determined in $0.01 \mathrm{~N}$ chloride solutions. 
cations could be associated with the microporosity of oxidic colloids, as reported by Breeuwsma (1973) and Tsuji et al. (1975). In addition, it is likely that the $\mathrm{NH}_{4}{ }^{+}$ions were incapable of exchanging completely with the adsorbed $\mathrm{Ca}$ and $\mathrm{Mg}$.

The third experiment gave further evidence in this last direction. Strong adsorption of $\mathrm{Ca}$ and to a lesser extent of $\mathrm{Mg}$ by oxidic colloids was indicated also by the $\mathrm{Ca} / \mathrm{K}$ adsorption preference curves (Fig. 1 ). These curves show that the adsorption preference of $\mathrm{Ca}$ over $\mathrm{K}$ is greater for the oxidic Honokaa and Halii samples than for the montmorillonitic Waialua sample. Moreover, the preference for $\mathrm{Ca}$ could be enhanced in the oxidic soils by raising the $\mathrm{pH}$ of the suspension (Fig. 2) and by phosphate adsorption (Fig. 3). Moreover, the data in Table III demonstrate the effects of adsorbed phosphate on the subse-

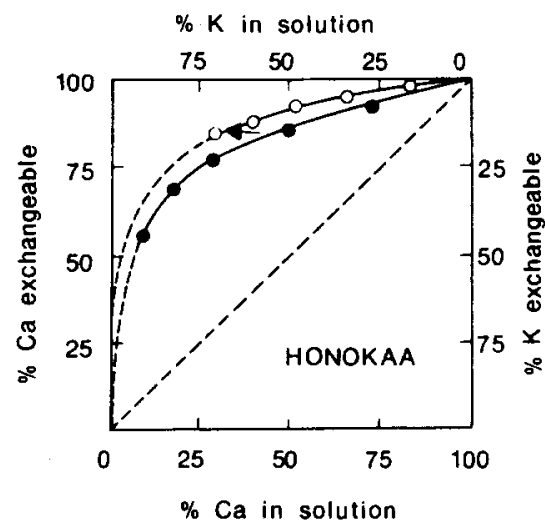

$\longrightarrow \mathrm{pH} 4.8$

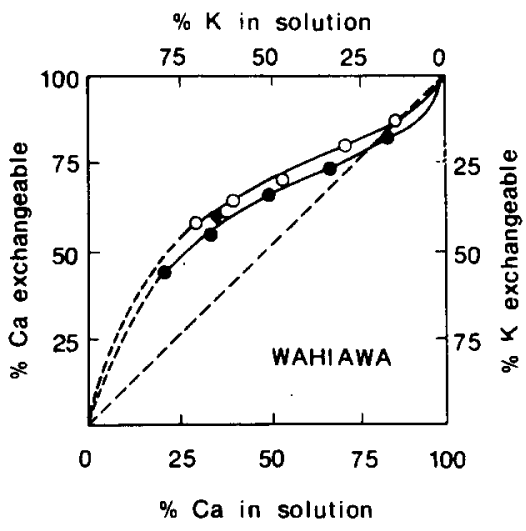

$\multimap \mathrm{pH} 5.8$

-.-. no preference line

Fig. 2. Cation adsorption preference curves for the Honokaa and Wahiawa soil samples as influenced by $\mathrm{pH}$, when determined in $0.01 \mathrm{~N}$ chloride solutions.

\section{TABLE III}

Effect of adsorbed phosphate added as $\mathrm{NH}_{4} \mathrm{H}_{2} \mathrm{PO}_{4}$ on $\mathrm{Ca}$ and $\mathrm{K}$ adsorption from $0.01 \mathrm{~N}$ chloride solutions at $\mathrm{pH} 4.8$

\begin{tabular}{lclll}
\hline Soil & $\begin{array}{l}\text { P treatment } \\
(\mu \mathrm{gP} / \mathrm{g} \text { soil) }\end{array}$ & $\begin{array}{l}\text { m mol P/ } \\
100 \mathrm{~g} \text { soil }\end{array}$ & & \multicolumn{2}{l}{$\begin{array}{l}\text { Increase in cation adsorption } \\
\text { (mequiv./100 g soil) }\end{array}$} \\
\cline { 3 - 5 } & & & $\mathrm{Ca}$ & $\mathrm{K}$ \\
\hline Honokaa & 1,500 & 4.8 & 1.90 & 0.96 \\
& 3,000 & 9.6 & 3.25 & 2.19 \\
Halii & 750 & 2.4 & 1.04 & 0.28 \\
& 1,500 & 4.8 & 2.13 & 0.76 \\
Wahiawa & 375 & 1.2 & 0.57 & 0.27 \\
& 750 & 2.4 & 1.37 & 0.47 \\
\hline
\end{tabular}




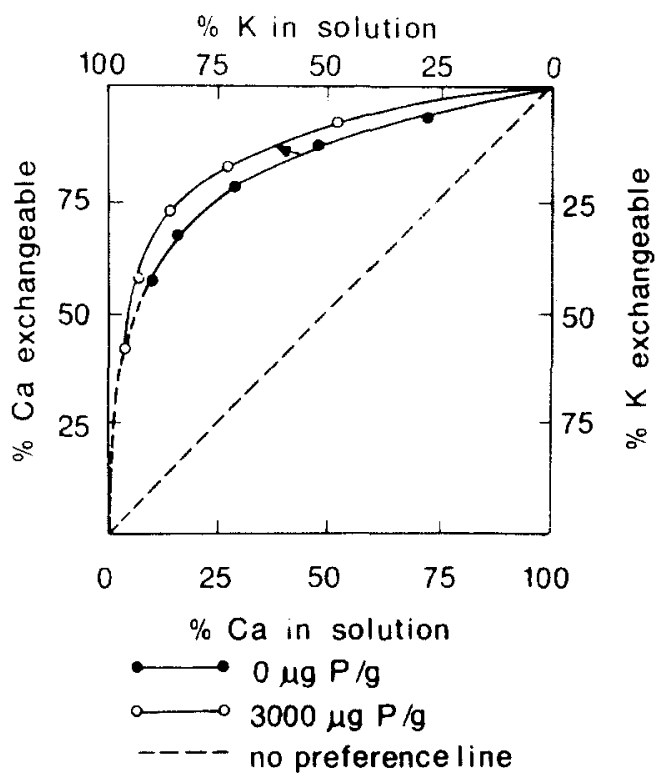

Fig. 3. Cation adsorption preference curves for $\mathrm{Ca} / \mathrm{K}$ ion pairs for Honokaa soil samples as influenced by adsorbed phosphate, when determined in $0.01 \mathrm{~N}$ chloride solutions.

quent increases in $\mathrm{Ca}$ and $\mathrm{K}$ adsorption, the former being at least two times greater. For the Waialua sample, the $\mathrm{P}$ adsorption was minor in comparison with the other soil samples and consequently its effect on cation adsorption was insignificant.

To explain these differences in ion adsorption and ion exchange behaviour between the soils, it is useful to distinguish three types of ion adsorption according to increasing strength of the bond between adsorbate and adsorbent: (1) non-specific adsorption of monovalent ions, mainly in the diffuse part of the electrical double layer (electrostatic bonding); (2) specific adsorption of divalent ions, mainly in the Stem-layer, e.g., $\mathrm{Mg}^{2+}, \mathrm{Ca}^{2+}, \mathrm{SO}_{4}{ }^{2-}$ (electrostatic bonding); (3) specific adsorption of ions, directly by the colloid surface, e.g., phosphates (chemical bonding).

It appears that the specific adsorption of divalent ions and phosphates is of particular importance in the case of oxidic colloids (Breeuwsma and Lyklema, 1973), whereas it is only of minor significance in 2:1 layer silicates. These latter have fewer $\mathrm{P}$ adsorption sites and generally a much smaller capability of increasing their negative surface charge through proton dissociation. Consequently, phenomena such as incomplete exchange between monovalent and divalent ions and positive interactions between adsorbed phosphate and cation adsorption will be relevant mainly to oxidic soils.

Logical implications are the underestimation of exchangeable cations, particularly divalent ones, when extractions with $\mathrm{NH}_{4}$-acetate are made in oxidic soils. As a result the base saturation will be underestimated as well. 
Moreover, specifically adsorbed $\mathrm{Ca}$ (and probably for similar reasons sulfate) will interfere with $\mathrm{PZC}$ measurements in the presence of $\mathrm{Na}$ - or $\mathrm{K}$-chlorides, as will be discussed in the following section.

Point of zero charge (PZC) measurements; effects of specifically adsorbed ions on the PZC

The cation exchange capacity (CEC), measured at $\mathrm{pH} 7$, is widely used as a criterion for soil characterization and classification. For soils which contain appreciable amounts of variable-charge colloids (e.g., many moderately acid, oxidic soils), however, the CEC is far from stable and measurements taken at pH 7 may thus bear little relevance to reality. In an effort to find a more satisfactory criterion, experiments were run to determine the possibilities of using the PZC of a soil instead. Generally, a low PZC $(<3.5)$ indicates the dominance of layer silicate clays, whereas increasing PZC values reflect an increasing prevalence of variable-charge colloids.

For the PZC to be of predictive value, it ought to be fairly constant. However, depending on the nature of the supporting electrolyte, considerable shifts in PZC have been reported. With $\mathrm{Na}_{2} \mathrm{SO}_{4}$ it moved to higher and with $\mathrm{CaCl}_{2}$ to lower values in comparison with $\mathrm{NaCl}$ (Breeuwsma and Lyklema, 1973; Keng and Uehara, 1973). Similar shifts were observed in the present study (Table IV), but the $\mathrm{pH}^{\circ}$ method used allowed a more detailed evaluation of these shifts than is possible from the common intersection points of potentiometric titration curves. Thus, the effects on the $\mathrm{pH}^{0}$ values of lowering the concentration of the supporting electrolyte and of liming or any increase in exchangeable Ca could be determined easily. As shown in Tables IV and $\mathrm{V}$, only the $\mathrm{pH}^{\circ}$ measurements in $\mathrm{CaCl}_{2}$ were not affected by these treatments, whereas for $\mathrm{NaCl}$ and $\mathrm{Na}_{2} \mathrm{SO}_{4}$ considerable increases in $\mathrm{pH}^{\circ}$ occurred.

In case of phosphate adsorption, chemical bonding between adsorbate and adsorbent leads to an increase in the net negative surface charge and a lowering of the PZC. The latter was confirmed for phosphated samples of

\section{TABLE IV}

Values of $\mathrm{pH}^{0}$ determined for different salts at concentrations of 0.005 and $0.05 \mathrm{~N}$

\begin{tabular}{|c|c|c|c|c|c|c|}
\hline \multirow[t]{3}{*}{ Soils } & \multicolumn{6}{|c|}{$\mathrm{pH}^{\mathbf{0}}$ values } \\
\hline & \multicolumn{2}{|l|}{$\mathrm{CaCl}_{2}$} & \multicolumn{2}{|l|}{$\mathrm{NaCl}$} & \multicolumn{2}{|l|}{$\mathrm{Na}_{2} \mathrm{SO}_{4}$} \\
\hline & $0.005 N$ & $0.05 N$ & $0.005 N$ & $0.05 N$ & $0.005 N$ & $0.05 N$ \\
\hline $\begin{array}{l}\text { Honokaa } \\
\text { Halii } \\
\text { Wahiawa }\end{array}$ & $\begin{array}{l}4.25 \\
4.05 \\
3.75 \\
\end{array}$ & $\begin{array}{l}4.25 \\
4.00 \\
3.75\end{array}$ & $\begin{array}{l}4.75 \\
5.10 \\
4.60\end{array}$ & $\begin{array}{l}4.50 \\
4.80 \\
4.20\end{array}$ & $\begin{array}{l}5.40 \\
5.75 \\
5.35\end{array}$ & $\begin{array}{l}5.10 \\
5.50 \\
5.20\end{array}$ \\
\hline
\end{tabular}


TABLE V

Effects of liming on $\mathrm{pH}^{\circ}$ values determined in $0.05 \mathrm{~N}$ solutions of $\mathrm{CaCl}_{2}, \mathrm{NaCl}$ and $\mathrm{Na}_{2} \mathrm{SO}_{4}$ in relation to exchangeable $\mathrm{Ca}+\mathrm{Mg}$

\begin{tabular}{|c|c|c|c|c|c|}
\hline \multirow[t]{2}{*}{ Soils } & \multirow[t]{2}{*}{ Treatment } & \multirow{2}{*}{$\begin{array}{l}\text { Exchangeable } \\
\mathrm{Ca}+\mathrm{Mg} \\
\text { (mequiv./100 g) }\end{array}$} & \multicolumn{3}{|c|}{$\mathrm{pH}^{0}$ values } \\
\hline & & & $\mathrm{CaCl}_{2}$ & $\mathrm{NaCl}$ & $\mathrm{Na}_{2} \mathrm{SO}_{4}$ \\
\hline \multirow[t]{2}{*}{ Halii } & unlimed & 6.66 & 4.00 & 4.80 & 5.50 \\
\hline & limed & 8.12 & 4.05 & 5.70 & 6.25 \\
\hline \multirow[t]{2}{*}{ Wahiawa } & unlimed & 5.13 & 3.75 & 4.20 & 5.20 \\
\hline & limed & 10.84 & 3.80 & 5.80 & 6.70 \\
\hline
\end{tabular}

TABLE VI

Values for $\mathrm{pH}^{\circ}$ as determined in $0.05 \mathrm{~N}$ salts for samples previously equilibrated with various rates of calcium and phosphate

\begin{tabular}{|c|c|c|c|c|}
\hline \multirow[t]{2}{*}{ Soils } & \multicolumn{2}{|l|}{ Treatments } & \multicolumn{2}{|c|}{$\mathrm{pH}^{\circ}$ valúes } \\
\hline & $\begin{array}{l}\text { added } \mathrm{Ca} \\
\text { (mequiv. } / 100 \mathrm{~g} \text { ) }\end{array}$ & $\begin{array}{l}\text { added P } \\
\text { (ppm) }\end{array}$ & $\mathrm{CaCl}_{2}$ & $\mathrm{NaCl}$ \\
\hline \multirow[t]{5}{*}{ Halii } & 0 & 0 & 4.10 & 4.45 \\
\hline & 2.7 & 100 & 4.10 & 4.70 \\
\hline & 5.3 & 100 & 4.10 & 5.25 \\
\hline & 2.7 & 800 & 3.80 & 4.40 \\
\hline & 5.3 & 800 & 3.90 & 4.60 \\
\hline \multirow[t]{5}{*}{ Wahiawa } & 0 & 0 & 3.85 & 4.30 \\
\hline & 2.7 & 100 & 3.80 & 4.60 \\
\hline & 5.3 & 100 & 3.85 & 5.30 \\
\hline & 2.7 & 800 & 3.65 & 4.05 \\
\hline & 5.3 & 800 & 3.65 & 4.35 \\
\hline
\end{tabular}

the Halii and Wahiawa soils. Again the effect was most clearly reflected by $\mathrm{pH}^{0}$ values measured in $\mathrm{CaCl}_{2}$ (Table VI).

Although these results may have been influenced by the exchangeable cations present in the samples (see Table I), all these shifts were in the expected directions and can be explained logically by distinguishing between the various adsorption and bonding mechanisms already mentioned.

Most likely, a substantial part of the $\mathrm{Ca}$, whether added or already present in the samples, will be specifically adsorbed in the Stern-layer, a process ruled by the colloid surface charge $\left(\sigma_{0}\right)$. Na adsorption, being non-specific, will, however, be the combined effect of both surface charge and counter charge (mainly from Ca) of adsorbed ions in the Stern-layer. Thus, particularly for the Honokaa and Halii samples which retain Ca very strongly, a $\mathrm{pH}^{0}$ measure- 
ment in $\mathrm{CaCl}_{2}$ is more likely to indicate the $\mathrm{PZC}$ than similar measurements in $\mathrm{NaCl}$ or $\mathrm{Na}_{2} \mathrm{SO}_{4}$. This conclusion is supported by the measurements on phosphated samples, which indicated a lowering of the PZC by 0.2 to $0.3 \mathrm{pH}$ units (determined in $\mathrm{CaCl}_{2}$ ), due to the adsorption of $800 \mathrm{ppm} \mathrm{P} \mathrm{(Table} \mathrm{VI).}$

The investigated problems arise largely from the presence of both positive and negative charges over a fairly wide $\mathrm{pH}$ range above and below the $\mathrm{PZC}$ (Breeuwsma, 1973). Consequently, both anion and cation adsorption will occur simultaneously over that $\mathrm{pH}$ range and will be interdependent. This interdependence, as well as the specific $\mathrm{Ca}$ adsorption, will equally affect the outcome of PZC measurements, whether done by potentiometric titrations or by the proposed $\mathrm{pH}^{0}$ method. Not taking into account these factors may lead to considerable confusion in the possible use of $\mathrm{PZC}$ values for soil characterization purposes.

In any case, more experimentation on different soils will be required to test the method and the effects of various mixtures of different types of adsorbents. Eventually, this may result in a better appreciation of the distinctive chemical properties of oxidic soils due to their variable-charge type colloids. Not only would then a better characterization of these soils be possible, but some practical indications on soil fertility management aspects, such as liming and phosphate fertilization could well follow.

\section{ACKNOWLEDGEMENTS}

Many thanks are due to the members of the Department of Agronomy and Soils at the University of Hawaii. I am particularly indebted to Dr. Robert L. Fox for providing the assistantship, which made this study possible, but also for his valuable advise and criticism during the course of the various investigations.

Furthermore, I would like to acknowledge the encouragement received from Dr. J.A. Mann in dealing with the colloid chemical aspects of this study.

\section{REFERENCES}

Breeuwsma, A., 1973. Adsorption of ions on hematite $\left(\alpha \mathrm{Fe}_{2} \mathrm{O}_{3}\right)$. Meded. Landbouwhogesch. Wageningen, 73-1.

Breeuwsma, A. and Lyklema, J., 1973. Physical and chemical adsorption of ions in the electrical double layer on hematite $\left(\alpha \mathrm{Fe}_{2} \mathrm{O}_{3}\right)$. J. Colloid Interf. Sci., 43: 437-448.

Hingston, F.J., Atkinson, R.J., Posner, A.M. and Quirk, J.P., 1968. Specific adsorption on goethite. Trans. Int. Congr. Soil Sci., 9th, I: 669-678.

Juo, A.S.R. and Maduakor, H.O., 1974. Phosphate sorption of some Nigerian soils and its effect on cation exchange capacity. Comm. Soil Sci. Plant Anal., 5(6): 479-497.

Kamprath, E.J., Nelson, W.L. and Fitts, J.W., 1956. The effect of pH, sulphate and phosphate concentrations on the adsorption of sulphate by soils. Soil Sci. Soc. Am., Proc., 20: 463--466.

Keng, J. and Uehara, G., 1973. Chemistry, mineralogy and taxonomy of Oxisols and Ultisols. Soil Crop Sci. Soc. Fla., Proc., 33: 119-125. 
Kinjo, T. and Pratt, P.F., 1971. Nitrate adsorption, II. In competition with chloride, sulphate and phosphate. Soil Sci. Soc. Am., Proc., 35: 725-728.

Matsusaka, Y. and Sherman, G.D., 1964. Lime requirements of Hawaiian soils. Hawaii Farm Sci., 13(3): 5-7.

Mekaru, T. and Uehara, G., 1972. Anion adsorption in ferruginous tropical soils. Soil Sci. Am., Proc., 36: 296-300.

Mikami, D.T. and Kimura, H.S., 1964. Special features of lime deficient tropical soils. Hawaii Farm Sci., 13: 10-11.

Parks, G.A. and De Bruyn, L.P., 1962. The zero point of charge of oxides. J. Phys. Chem., 66: $967-972$.

Rixon, A.J., 1966. Effects of heavy applications of lime to soils derived from volcanic ash on the Hilo and Hamakua Coast, Island of Hawaii. Hawaii Agric. Exp. Sta., Univ. Hawaii Tech. Bull., 47.

Tsuji, G.Y., Watanabe, R.T. and Sakai, W.S., 1975. Influence of soil microstructure on water characteristics of selected Hawaiian soils. Soil Sci. Soc. Am., Proc., 39: 28-33.

Van Raij, B. and Peech, M., 1972. Electrochemical properties of some Oxisols and Alfisols of the tropics. Soil Sci. Soc. Am., Proc., 36: 587-593. 